\title{
Følelser, ting og museologi
}

At der er en nær sammenhæng mellem tingene og museologien turde være velkendt. At der er følelser med i spillet kan heller ikke komme bag på andre end teknokraterne. Kærlighed til tingene har formentlig været den største drivkraft overhovedet i museernes udvikling. I dag må du også elske museerne i medgang og modgang, hvis du vil lade disse sære institutioner fulde af ting og tolkninger fylde dit liv.

Der ligger også stor kærlighed bag dette nummer af Nordisk Museologi, som er tilegnet Per-Uno Ågren, tidsskriftets hovedredaktør gennem alle årene siden starten i 1993.

Ingen vil tro det, men faktum er, at Per-Uno, denne museernes førsteelsker, fylder 75 år! Derfor vil han holde op som redaktør af Nordisk Museologi.

At han nu vil være pensionist for alvor kommer som et chok både for vore trofaste læsere - og for den øvrige redaktion, som pludselig lades i stikken med en stor opgave, som Per-Uno hidtil har løst suverænt.

Alligevel besluttede vi i redaktionen at sætte redaktøren fra bestillingen et nummer for tidligt, fordi vi gerne ville takke ham for en stor indsats ved for en gangs skyld at lade et nummer tage udgangspunkt i ham selv.

Den øvrige redaktion og medlemmer af redaktionsrådet skulle skrive suppleret af artikler fra nogle af Per-Unos nære venner. Nordisk Museologi er Per-Unos kærlighedsbarn. Vi må bede om tilgivelse både fra læserne og fra Per-Uno, hvis dette nummer ikke er plejet så omhyggeligt, som vanligt. Kærlighed har det dog ikke skortet på!

Det er naturligt at lade Eva Silvén, svensk redaktionsråd, lægge ud med hvad der former sig som en begejstret anmeldelse af redaktørens sidste nummer: "En performativ museologi" med referencer til det store arrangement "Museum 2000", hvor Per-Uno havde en central rolle som arrangør og redaktør.

Marc Maure, norsk redaktionsråd, mindes den inspiration han fandt på Västerbottens Museum da han var med på en af Per-Unos mange internationale konferencer.

Göran Carlsson, gammel arbejds- og rejsekammerat beskriver i tekst og streg den internationale Per-Umeå, og Sune Jonsson, Sveriges store dokumentarfotograf, sender en fotografisk hilsen. 
Netop fotografiet er emnet for Bo Nilsson, en anden af Per-Unos nære venner, som fortæller om den store interesse for fotografiet de sidste årtier af 20. århundrede.

Bjørnar Olsen, norsk landsredaktør, kommer tingene til undsætning, de ting museerne lever af og for, men som har været truet i de traditionelle "museumsfag", som har været mere tiltrukket af de social-antropologiske aspekter.

Gaynor Kavanagh, også en af Per-Unos gamle museologiske venner, undrer sig over, hvorfor vi i den grad klynger os til ting, som vi helst vil røre for at få del i deres kraft. Mon hun ved, at Per-Uno i 1982 netop skrev om tingene: "Just $i$ dessa avseenden, $i$ sin sensualism, är utställningen överlägsen alle andre medier".

Guдny Gerdur Gunnarsdóttir, islandsk landsredaktør, fortæller en væsentlig historie om, hvorledes ting kan blive til kulturarv - også uden at være det.

Anne Aurasmaa, finsk redaktionsråd, beskriver hvorledes renæssancens samlinger i deres opstilling afspejlede tidens verdensbillede og Janne Vilkuna, finsk landsredaktør, har læst skabelsesberetningen som museologi.

Afspejlede den første udstilling i Londons nye Naturhistoriske museum (1884) udviklingslæren? I al fald brød den med traditionen for de systematiske opstillinger beretter Eric Hedqvist, gammel ven og medarbejder.

Danmarkshistorier 1660-2000 hedder Nationalmuseets nye udstilling i København. Det er også titlen på Anette Vasströms, dansk redaktionsråd, beretning om, hvorledes udstillingen blev til, og hvordan den blev modtaget.

Denne ydmyge klummeskriver, dansk landsredaktør, forsøger i "Museumsudstillingen" med afsæt i Per-Unos pionerarbejde at bidrage til museologiens terminologi.

At museer er mere end ting og samlinger, men også pædagogiske institutioner demonstrerer David Anderson, gammel museologisk ven af Per-Uno med al ønskelig tydelighed i sin artikel "Our Enlightenment.

Det er naturligt og en kær pligt netop i dette nummer at trykke den bibliografi over Per-Uno Ågrens trykte museologiske bidrag, som John Aage Gjestrum nåede at samle og redigere, men ikke at se på tryk.

Som klassikeren har vi valgt at bringe "Att ställa ut historia" af Per-Uno Ågren, en artikel som fik meget stor indflydelse på os alle, da den dukkede op i 1972.

Den museologiske poesi skal ikke mangle og er denne gang overladt til Eske K. Mathiesen, som både er folkemindesamler og lyriker. 